I NTER NATIONAL MONETARY FUND

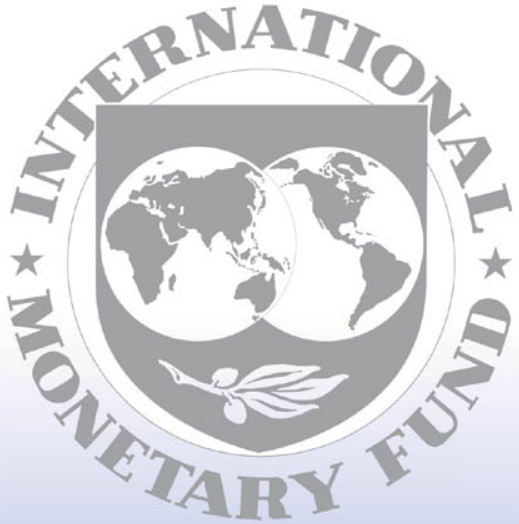

Staff

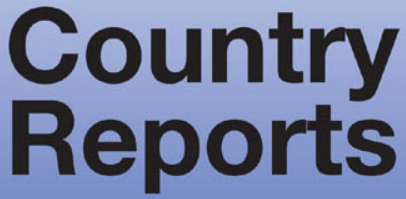




\section{Guernsey: Report on Observance of Standards and Codes_FATF Recommendations for Anti-Money Laundering and Combating the Financing of Terrorism}

This Report on the Observance of Standards and Codes on the FATF Recommendations for Anti-Money Laundering and Combating the Financing of Terrorism for Guernsey was prepared by a staff team of the International Monetary Fund using the assessment methodology adopted by the FATF in February 2004 and endorsed by the Executive Board of the IMF in March 2004. The views expressed in this document, as well as in the full assessment report, are those of the staff team and do not necessarily reflect the views of the Government of Guernsey or the Executive Board of the IMF.

Copies of this report are available to the public from

International Monetary Fund • Publication Services

700 19th Street, N.W. • Washington, D.C. 20431

Telephone: (202) 6237430 • Telefax: (202) 6237201

E-mail: publications@imf.org • Internet: http://www.imf.org

\section{International Monetary Fund \\ Washington, D.C.}




\section{GUERNSEY}

Report on Observance of Standards and Codes (ROSC)_FATF Recommendations for Anti-Money Laundering and Combating the Financing of Terrorism (AML/CFT)

Prepared by the Legal Department

Approved by Sean Hagan

December 22, 2010

Table of Contents

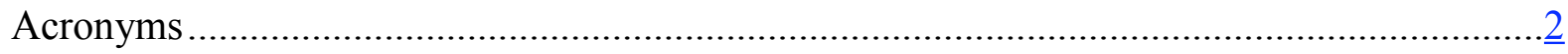

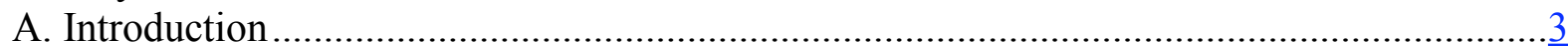

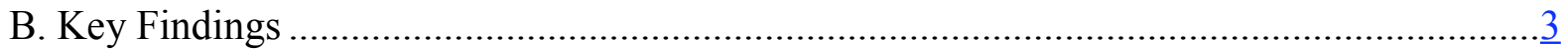

C. Legal Systems and Related Institutional Measures..........................................................

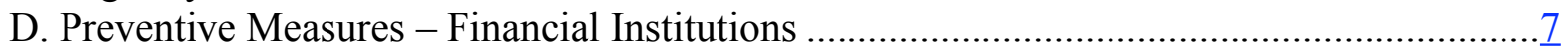

E. Preventive Measures - Designated Non-Financial Businesses and Professions .................... 9

F. Legal Persons and Arrangements \& Non-Profit Organizations ….....................................10

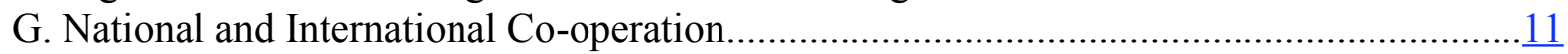

Summary Table of Observance and Key Recommendations ...............................................13

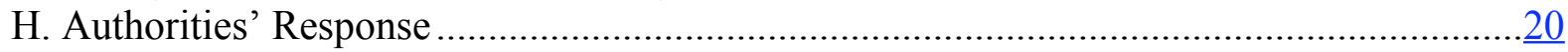


Acronyms

AGCC Alderney Gambling Control Commission

AML/CFT Anti-Money Laundering and Combating the Financing of Terrorism

CDD Customer Due Diligence

DNFBP Designated Non-Financial Businesses and Professions

FATF Financial Action Task Force

FIU Financial Intelligence Unit

FIS Financial Intelligence Service

FSB Financial Services Businesses

FT Financing of Terrorism

GFSC Guernsey Financial Services Commission

LEA Law Enforcement Agency

LEG Legal Department of the IMF

LLP Limited Liability Partnership

ML Money Laundering

MLA Mutual Legal Assistance

NPO Nonprofit Organization

OEM Other Enforceable Means

PB Prescribed Businesses

PEP Politically-exposed person

POC Proceeds of Crime Law

STR Suspicious Transaction Report

TCSP Trust and Company Service Providers

UN United Nations Organization

UNSCR United Nations Security Council Resolution 


\section{A. Introduction}

This Report on the Observance of Standards and Codes for the FATF 40 Recommendations for Anti-Money Laundering $(A M L)$ and 9 Special Recommendations on Combating the Financing of Terrorism (CFT) was prepared by the Legal Department of the IM $\mathrm{F}^{1}$. The report provides a summary of the AML/CFT measures in place in the Bailiwick of Guernsey and of the level of compliance with the FATF $40+9$ Recommendations, and contains recommendations on how the AML/CFT system could be strengthened. The assessment is based on the information available at the time of the mission from May 17, 2010 to June 1, 2010 and was conducted using the 2004 Assessment Methodology. The views expressed here, as well as in the full assessment report, are those of the assessment team and do not necessarily reflect the views of the Government of the Bailiwick of Guernsey or the Executive Board of the IMF.

\section{B. Key Findings}

\section{Guernsey's comprehensive AML/CFT legal framework provides a sound basis} for an effective AML/CFT regime. Most shortcomings identified during the assessment are technical in nature. Some of these deficiencies were addressed by the authorities immediately after the onsite visit. Money laundering (ML) and the financing of terrorism (FT) are criminalized fully in line with the FATF standard and the legal framework provides an ability to freeze and confiscate assets in appropriate circumstances. As of the assessment date, there had been no prosecutions or convictions for terrorist financing. Guernsey is able to freeze the assets of those covered by UN Security Council Resolutions 1267 and 1373 and successor regulations through administrative orders issued by the Attorney General.

The Financial Intelligence Unit (FIU) for the Bailiwick of Guernsey, a law enforcement type of FIU, is the Financial Intelligence Service (FIS). The FIS primarily performs a pre-investigative and intermediary role before disseminating relevant information not only to domestic authorities but also to counterpart FIUs. There is clear separation between the intelligence and the investigative side of the handling of the suspicious transaction reports, enhancing the transparency of the process. However, the FIS and the other law enforcement agencies should endeavor to enhance their performance in terms of cases for investigation for money laundering activity, particularly as a stand-alone offense.

\footnotetext{
${ }^{1}$ The assessment team consisted of: Francisco R. Figueroa (LEG, team leader), Margaret Cotter, Marilyne Landry, (All LEG, legal and financial sector experts, respectively); and Gabriele Dunker (legal expert), Boudewijn Velherst (financial intelligence unit expert), and Gary Sutton (financial sector expert). All experts under the supervision of the Legal Department.
} 
The Bailiwick, through the Financial Services Commission (GFSC), has established a risk-based approach to $A M L / C F T$. The preventive measures are largely in line with the FATF Recommendations. The GFSC has adequate authority and powers to supervise financial institutions, including money transfer systems with respect to compliance with existing AML/CFT laws, regulations, and rules. However, powers to sanction financial institutions for noncompliance, particularly the regime for applying discretionary financial penalties could be enhanced to ensure that the penalties are dissuasive and proportionate to the severity of the violation or level of noncompliance.

The preventive measures for DNFBPs mirror those for financial institutions. Supervision and regulation of DNFBPs, with the exception of eCasinos, is conducted by the GFSC. ECasinos are regulated and supervised by the Alderney Gambling Control Commission (AGCC). Shortcomings noted within the DNFBPs were related to CDD, recordkeeping, risks associated to non face-to-face transactions, licensing measures, and effectiveness issues in the eCasinos sector. There were also a number of shortcomings noted within the legal framework applicable to DNFBPs dealing with exemptions and guidance to the sectors.

Sound measures are in place to ensure that legal persons incorporated in the Bailiwick are transparent and that accurate, adequate and current information concerning beneficial ownership is available to law enforcement and other competent authorities. Trusts are recognized and well established under Guernsey law but are not subject to any registration or filing requirements. In most cases trusts require involvement of a regulated trustee who is subject to the full range of AML/CFT requirements. For trust arrangements that are not administered by a licensed TCSP, some concerns remain with respect to the availability of accurate and complete beneficial ownership information. A registration regime for NPOs has been established although it does not apply to all charitable organizations. Information on the purpose and objectives of the NPOs and the identity of the persons who own, control or direct their activities is not publicly available. Sanctions for noncompliance with registration requirements are not effective and dissuasive.

Guernsey has effective mechanisms for coordination and cooperation among all domestic A M L/C FT stakeholders including an active policy coordination committee. The legal framework for mutual legal assistance (MLA) and extradition is sound and the majority of requests seem to be processed in a timely and constructive manner. Bailiwick law allows for the provision of all types of assistance as required by the Vienna and Palermo Conventions in money laundering, terrorism financing or predicate offense cases.

Both money laundering and terrorism financing are extraditable offenses. The Guernsey extradition regime is still managed by the United Kingdom (U.K.) authorities by virtue of the U.K. Extradition Act 1989. No extraditions are on record under that Act, but formally the legal framework is comprehensive and solid. As for non MLA related 
assistance, although limited in its possibilities to directly collect financial information at intelligence level, the cross-border cooperation at FIS and police level constitutes an essential part of their assignment. The FIS and police follow a constructive approach to all serious requests and consent to use the supplied information for intelligence purposes has never been refused.

\section{Legal Systems and Related Institutional Measures}

\section{Money Laundering Provisions}

The Bailiwick has taken a two strand approach to criminalizing money laundering, differentiating between drug trafficking offenses and all other predicate offenses. In both cases, money laundering is criminalized fully in line with the international standard. The Bailiwick is a party to the Vienna but not to the Palermo Convention and all technical aspects of the ML offenses as defined in the Vienna and Palermo Conventions are complied with. In particular, all categories of predicate offences listed in the international standard are covered. The money laundering offenses extend to any type of property that represents the proceeds of crime by the money laundering provisions and all acts constituting money laundering or ancillary offences to money laundering are criminalized in line with the international standard. The mens rea requirement varies depending on the money laundering offences applicable in the specific case. At a minimum and with respect to all money laundering offenses, a person may be held criminally liable if he acted intentionally and with the knowledge that the property involved stems from a criminal source. Based on an English common law principle, intent may be inferred from objective factual circumstances. Criminal liability also extends to legal persons.

While no shortcomings have been identified in the legal framework, concerns remain with respect to the implementation of the money laundering provisions. Given the size of the Bailiwick's financial sector and its status as an international financial center, the modest number of cases involving money laundering by financial sector participants and the disconnect between the number of money laundering cases investigated versus the number of cases prosecuted and eventually resulting in a conviction calls into question the effective application of the ML provisions.

\section{Financing of Terrorism Provisions}

\section{Guernsey is a party to the International Convention for the Suppression of the} Financing of Terrorism and has criminalized terrorism financing fully in line with the international standard. The provisions of the Terrorism law and the Terrorism (United Nations Measures) (Channel Islands) Order 2001 allow for a prosecution of the provisions or collection of funds with the unlawful intention or in the knowledge that they are to be used in full or in part to carry out a terrorist act, by a terrorist organization or by an individual 
terrorist. At the time of the on-site visit, there had been no prosecutions or convictions for terrorist financing.

\section{Confiscation}

Guernsey has a comprehensive legal framework to identify, freeze, seize and confiscate criminal assets. As additional financial sector money laundering and predicate activity is detected, the legal provisions should be used to secure and confiscate proceeds of such criminal activities.

Freezing of Funds

Guernsey's legal framework and procedures for implementing UNSCRs 1267 and 1373 are largely sufficient but it is too soon to assess the effectiveness of recent enhancements in the guidance that the authorities provide to the financial sector and others. The legal framework should more clearly reflect that designated persons are not to receive prior notice of freezing actions.

\section{Financial Intelligence Unit}

The Financial Intelligence Unit (FIU) for the Bailiwick of Guernsey is the Financial Intelligence Service (FIS), specifically designated as such by law on May 17, 2010, officially recognizing the long-standing practice of channeling all STRs to the Financial Intelligence Service as a subdivision within the Financial Investigation Unit of the Customs and Immigration Service. Although a law enforcement type Financial Intelligence Unit, the FIS primarily performs a pre-investigative and intermediary role before disseminating relevant information not only to domestic authorities but also to counterpart FIUs. Consequently the dissemination rate is rather high, ranging from 70 percent to 86 percent of the total number of STRs received.

The FIS has access to a whole range of law enforcement, administrative and commercial information but makes little use of the administrative sources. Direct access to financial information is quite restricted: there is only a legal permission to query the reporting entity for information complementary to the initial disclosure and the possibility to request the supervisory authorities for information in their possession. Access to other additional financial information is only available through a court order. The FIS is quite active in the international scene and systematically shares information for intelligence purposes with its counterpart FIUs.

Overall, the FIU/FIS is adequately performing its role as a key player in the $\mathrm{AML}$ /CFT system. It has developed a relation of trust and openness with the financial sector. The system is geared to ensure that the STRs are appropriately dealt with in a focused and professional manner. The clear separation between the intelligence and the investigative side of the handling of the reports particularly enhances the transparency of the process. The 
FIS should however endeavor to enhance its performance in terms of cases for investigation for money laundering activity, particularly as a stand-alone offense. The system is still predominantly geared to take on the local predicate criminality and related money laundering. The challenge of investigating and prosecuting foreign predicated money laundering as an autonomous offense working on the basis of the evidence gathered in its own jurisdiction still has to be met.

The law enforcement authorities are adequately resourced and trained and have a sufficient legal arsenal at their disposal to effectively conduct a money laundering investigation, but still the results are modest. Great emphasis is placed on making information available to the overseas agencies, which is commendable in itself but carries the risk of overreliance on foreign law enforcement taking the initiative, while the money laundering activity in the Bailiwick continues to take place. As for the judicial side progress is being made, as witnessed by the pending autonomous money laundering case. Still, the judicial authorities should further develop their expertise in this domain by putting more effort and emphasis on the development of case law on stand-alone money laundering based on evidence collected in and by its own jurisdiction.

The cross-border cash declaration regime installed by the Cash Controls Law 2007 brought the Bailiwick in line with the corresponding European Community Regulation 1889/2005 and adequately covers the physical and freight cross-border cash transportation. The controls are effectively implemented, with frequent declarations and STRs filed by the Post Office which actually resulted in a sizable amount seized and confiscated. As for cash transported by post the Bailiwick authorities have recently taken corrective action to address the deficiencies in the declaration regime by bringing the mail declaration system in line with the cash importation regime by freight.

\section{Preventive Measures - Financial Institutions}

The primary legislative foundation for customer due diligence (CDD) and other preventive measures is the Proceeds of Crime (Bailiwick of Guernsey) (POC) Law 1999. The specific requirements are set out in detail in secondary legislation in the Criminal Justice (Proceeds of Crime) (Financial Services Businesses) (Bailiwick of Guernsey) Regulations, 2007 (FSB Regulations). This is supplemented by a Handbook issued by the GFSC in 2007 which includes further requirements-which qualify as other enforceable means (OEM)-as well as guidance. The updating of the requirements in 2007 followed extensive consultations with industry and sought to address all the requirements of the international standard.

The GFSC has established a risk-based approach to AML/CFT, including for preventive measures for financial institutions that add ress a vast majority of the CDD elements of the international standards in almost all respects and shortcomings identified during the assessment are largely technical. Customers and beneficial owners are required to be identified in all cases; detailed requirements apply to legal entities and 
trusts; enhanced due diligence is required for higher risk customers, including politically exposed persons (PEPs); records of customer identification must be kept up-to-date and all documentation, including transactions and customer information, must be retained for at least five years; and suspicious activity is effectively required to be reported to the FIU.

With respect to financial secrecy, there are no legal impediments that could inhibit the implementation of the FATF Recommendations. There are effective mechanisms in place to provide for the right of confidentiality of financial information as well as access to information by competent the authorities. There are requirements in place for financial institutions to pay special attention to all complex, unusual large transactions and all unusual patterns of transactions, which have no apparent economic or visible lawful purpose, as well as to business relations and transactions from countries which do not follow or insufficiently apply the FATF Recommendations.

\section{All categories of financial institutions appear to be reporting suspicious} transactions. The laws providing legal protection for those filing were recently amended to be limited to those acting in good faith and the tipping-off offence was also amended to eliminate any technical noncompliance with the international standard.

Financial institutions are required to establish internal programs and controls to implement the requirements of the $\mathrm{AML}$ /CFT laws, regulations, and rules; however, there is no requirement for maintaining an adequately resourced and independent audit function in financial institutions. Measures to prevent the establishment of shell banks and to prevent financial institutions from dealing with shell banks are adequate.

The GFSC has been given adequate authority and powers to supervise financial institutions, including money transfer systems, and ensure compliance with existing $\mathrm{AML} / \mathrm{CFT}$ laws, regulations, and rules. At the time of the visit, inspections of AML/CFT matters were risk-based and considered adequate in scope. Some financial institutions, as a result of the inspections, have been required to implement remedial measures to strengthen their overall AML/CFT preventive regime, including bringing their CDD information (including on beneficial owners) into line with the latest requirements, improving their internal control systems, and providing additional training.

The GFSC has also adequate powers to sanction financial institutions for noncompliance issues and has used these powers in numerous occasions; however, the discretionary financial penalties available to the GFSC are not considered dissuasive and proportionate. The GFSC can only impose fines for up to $£ 200,000$; which is considered too low, for violations of any provisions of the prescribed laws.

Nevertheless, the GFSC authorities need to exercise additional oversight to further strengthen the existing regime, particularly in certain aspects related to CDD. In this area, the authorities need to expand the list of higher-risk customers to which enhanced due diligence must be applied and consider including private banking and non- 
resident customers. In addition, the authorities should not permit reliance on attorneys and accountants from the United Kingdom and other Channel Islands as introducers, until they have been subject to AML/CFT regulations, and supervised for compliance, for a greater period of time.

\section{E. Preventive Measures - Designated Non-Financial Businesses and Professions}

The preventive measures for lawyers, accountants and estate agents are outlined in the Proceeds of Crime (Bailiwick of Guernsey) (POC) Law, 1999. The specific requirements are set out in the Criminal Justice (Proceeds of Crime) (Legal Professionals, Accountants and Estate Agents) Regulations, 2008 (PB Regulations). This is supplemented by a Handbook issued by the GFSC in 2008 which includes further requirements-which qualify as other enforceable means. Requirements for eCasinos are outlined the in Alderney eGambling Ordinance, 1999 and supported by the Alderney eGambling Regulations, 2009. Trust Company and Service Providers (TCSPs) and bullion dealers have the same requirements are financial services businesses.

The Guernsey Financial Services Commission (GFSC) is responsible for supervising lawyers, accountants, estate agents, TCSPs and bullion dealers. The Alderney Gambling Control Commission (AGCC) supervises eCasinos. Substantial efforts have been made in implementing preventative measures for all DNFBPs. However, risks in the eCasino sectors are not fully mitigated and some shortcomings exist in the implementation of preventative measures for DNFBPs supervised by the GFSC.

Customer due diligence measures are applied to all customers and beneficial owners. Detailed requirements apply to legal entities and TCSPs; on-going due-diligence is conducted on on-going business relationships; enhanced due diligence is conducted for higher risk categories including PEPs; records of customer identification are kept up to date and all documentation is retained for at least five years.

A number of shortcomings have been identified with respect to CDD and record keeping requirements for DNFBPs. On-line verification methods used by eCasinos are not sufficiently reliable; requirements to mitigate against the risk associated with non-face-toface transactions in the eCasinos sector are not in line with the standard; and not all eCasinos have effectively implemented the requirement to pay special attention to complex and unusual transactions.

The statutory framework and its implementation by DNFBPs supervised by the GFSC also had a number of shortcomings. The exemption for individuals who as act as a director for six companies or less is not in line with the standard; the exemption for accountants from CDD requirements on existing customers is defined too broadly; lawyers, accountants and estate agents are not required to determine potential customers are PEPs; guidance provided by the GFSC on low and high risk jurisdictions is contradictory; the 
GFSC has not identified legal arrangements and TCSPs as high risk; and reliance should not be placed on introducers or intermediaries who are DNFBPs.

Substantial efforts have also been made in implementing STR reporting and internal control requirements. Entities are required to report STRs to the FIU including attempted transactions; adequate protections exist for STR reporting and tipping off; entities are required to establish and maintain internal procedures to prevent ML and TF; policies and procedures are tested; compliance officers must be appointed and screening procedures are in place when hiring employees.

A number of improvements could be made to enhance the effectiveness of STR reporting and internal controls. The number of reports submitted by the eCasinos sector could be increased to better reflect the ML risk and the size of the industry. ECasinos should provide training to all their employees.

The GFSC and the AGCC have the necessary powers and authority to supervise the DNFBP sector. Both commissions have implemented robust supervisory programs that, with one exception, have the necessary resources to provide comprehensive oversight of the DNFBP sectors including the necessary sanctions and penalties to address non-compliance. Guidance issued by the commissions receives positive feedback from industry.

Although the AGCC does conduct extensive criminal background checks on individuals seeking an eGambling license the absence of consistent police record checks creates a risk that the industry may be infiltrated by criminals. Also, the resources dedicated to the supervision of TCSPs should be increased to address the reduced number of examination in this high risk sector.

\section{F. Legal Persons and Arrangements \& Non-Profit Organizations}

Guernsey and Alderney laws allows for the incorporation of limited, unlimited or mixed liability companies as well as of limited liability partnerships (LLPs), subject to registration with the Guernsey or Alderney companies registries. More than 18,000 companies were registered in Guernsey and 530 in Alderney at the time of the assessment. Sark does not provide for the incorporation of companies on the island.

The Bailiwick has three measures in place to obtain, maintain, and verify beneficial ownership information for companies and LLPs. Namely, for the majority of Guernsey companies, the requirement to have a registered agent, who in term has an obligation to "take reasonable steps" to ascertain the identity of persons who are beneficial owners of the company; for the majority of Bailiwick companies (Guernsey and Alderney) and limited partnerships, the requirement to utilize a licensed Trust and Company Service Provider (TCSP), who in turn is subject to and in most cases supervised for compliance with the CDD obligations under the AML/CFT regime; for all Bailiwick companies (Guernsey and Alderney) and limited partnerships, the obligation to provide certain beneficial 
ownership information to the relevant registry (Alderney companies registry, Guernsey company registry or Guernsey partnership registry) and to update such information.

In addition, all Bailiwick companies (Guernsey and Alderney) and limited partnerships have a legal obligation to maintain shareholder, director and partner registers and to file annual returns with the Alderney and Guernsey Company Registrars. The above mentioned measures are supported by investigative and other powers of LEAs and the GFSC to obtain access to information held by FSBs, TCSPs and other entities and persons. In sum, those measures put the Bailiwick in a very strong position to ensure that legal entities are transparent and that accurate, adequate and current information concerning beneficial ownership and control of all legal persons is available to law enforcement and other competent authorities.

Trusts have been recognized under Guernsey law for many years and the trust concept is well established in the island. The Trust (Guernsey) Law 2007 is the main pieces of legislation governing such legal arrangements. No statistics are maintained on the number of Guernsey trust arrangements or the volume of trust assets administered in Guernsey. Alderney and Sark law do not provide for the creation of trusts.

Trusts are not subject to any registration or filing requirements. However, with few exceptions, acting as a trustee is a regulated activity and, as such, is subject to the full range of $\mathrm{AML} / \mathrm{CFT}$ requirements, including the obligation to identify and verify the identity of beneficial owners and to keep such information complete, accurate and updated. Concerns remain with respect to the availability of accurate and complete beneficial ownership information for trust arrangements that are not administered by a licensed TCSP.

Substantive efforts have been made to mitigate the terrorism financing risks associated with NPO although a number of changes are required to enhance the effectiveness of the regime. A registration regime for NPOs has been established although it does not apply to all charitable organizations. Information exchange mechanisms both domestically and internationally are robust and the authorities have the capacity to undertake investigations relating to terrorism financing and NPOs. Efforts have been made to protect the NPO sector from terrorism financing through outreach and oversight but the outreach was not provided to the entire sector and oversight has been limited to manumitted organizations administered by TSCPs. Information on the purpose and objectives of the NPOs and the identity of the persons who own, control or direct their activities is not publicly available. Furthermore, sanctions for non-compliance with registration requirements are not effective and dissuasive.

\section{G. National and International Co-operation}

Guernsey has effective mechanisms for coordination and cooperation among all domestic AM L/CFT stakeholders including an active policy coordination committee. There is regular consultation and coordination on both policy and operational levels, and the 
ongoing development and refinement of a common vision and strategy including regular internal assessments against the strategy.

Mutual Legal Assistance and Extradition

The legal framework for mutual legal assistance ( $M L A)$ and extradition is sound and the majority of requests seem to be processed in a timely and constructive manner. Bailiwick law allows for the provision of all types of assistance as required by the Vienna and Palermo Conventions in money laundering, terrorism financing or predicate offense cases. The provision of MLA is not subject to any unreasonable, disproportionate or unduly restrictive conditions and the statistics provided by the authorities indicate that since 2007 the majority of requests have been implemented in an efficient and timely manner. Both money laundering and terrorism financing are extraditable offenses.

The Guernsey extradition regime is still managed by the U.K. authorities by virtue of the U.K. Extradition Act 1989, the Bailiwick being only marginally involved in the process. No extraditions are on record under that Act, but formally the legal framework is comprehensive and solid.

As for non MLA related assistance, although limited in its possibilities to directly collect financial information at intelligence level, the cross-border cooperation at FIS and police level constitutes a primordial part of their assignment, as shown by relatively high volume of information exchange traffic. Of the STRs disseminated, some 60 percent have an overseas destination. The FIS and police follow a constructive approach to all serious requests and consent to use the supplied information for intelligence purposes has never been refused. 
Summary Table of Observance and Key Recommendations

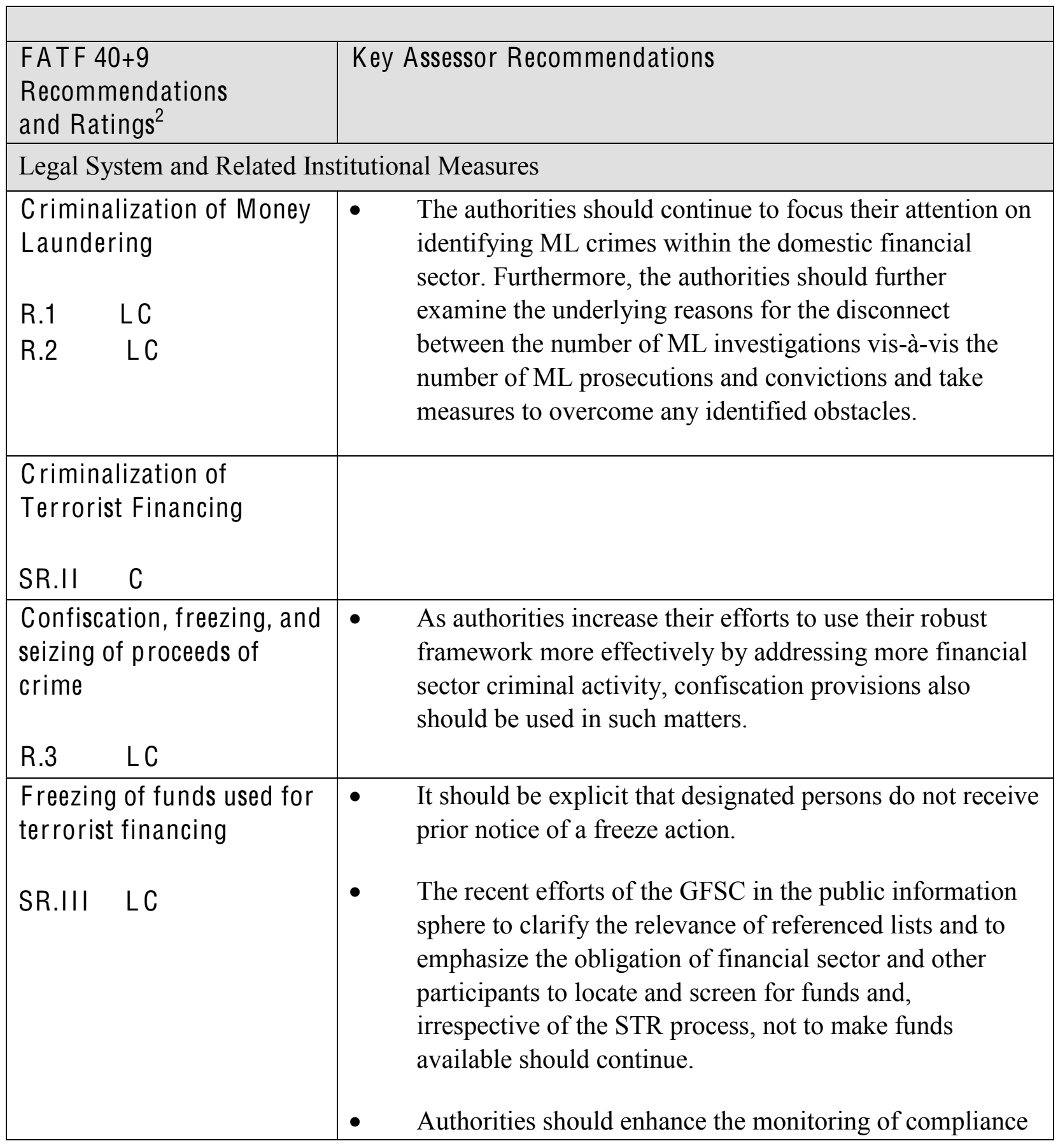

\footnotetext{
${ }^{2}$ Compliant (C): the Recommendation is fully observed with respect to all essential criteria. Largely compliant (LC): there are only minor shortcomings, with a large majority of the essential criteria being fully met. Partially compliant (PC): the country has taken some substantive action and complies with some of the essential criteria. Non-compliant (NC): there are major shortcomings, with a large majority of the essential criteria not being met. Not applicable (NA): a requirement or part of a requirement does not apply, due to the structural, legal or institutional features of a country.
} 


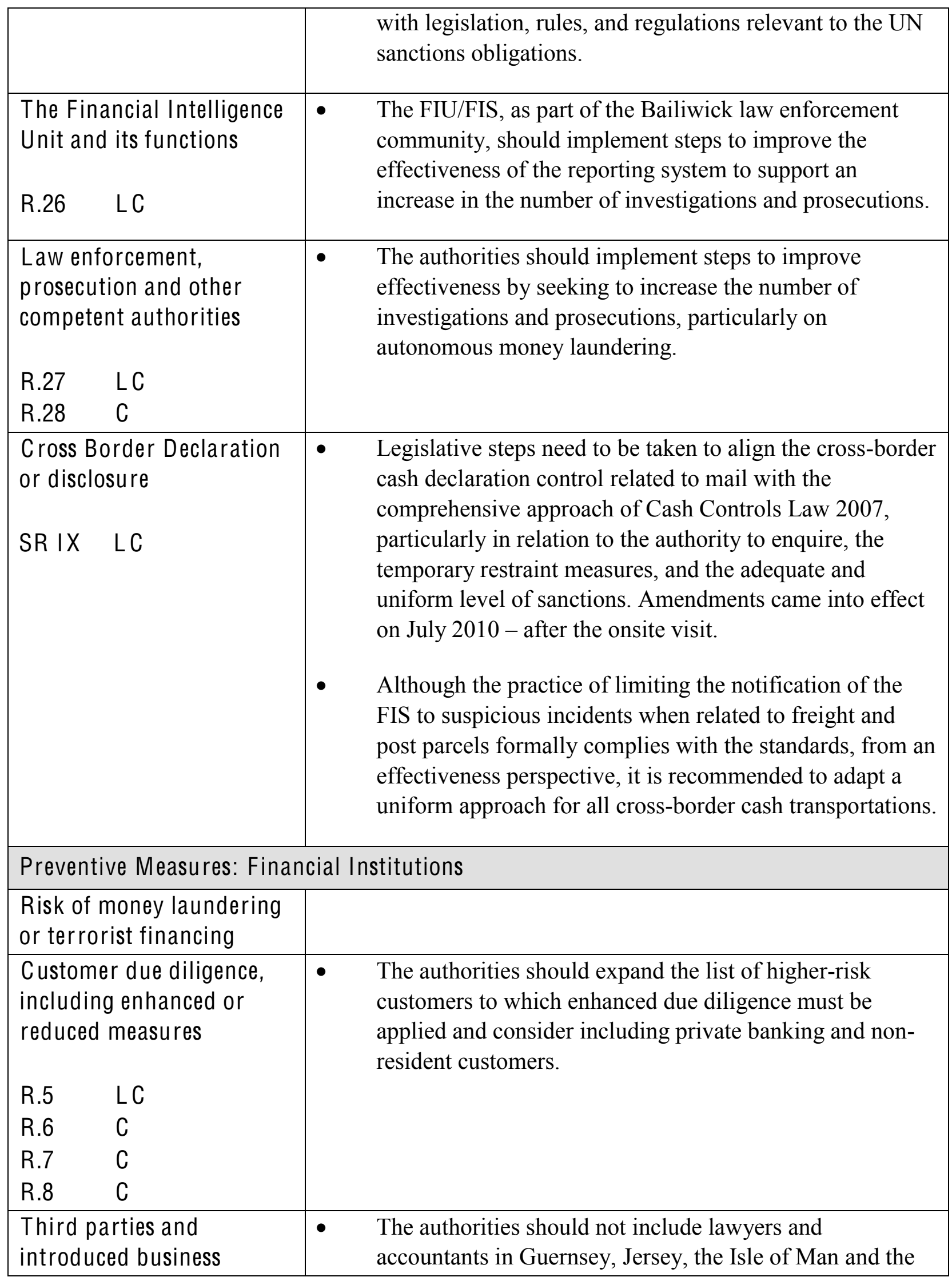




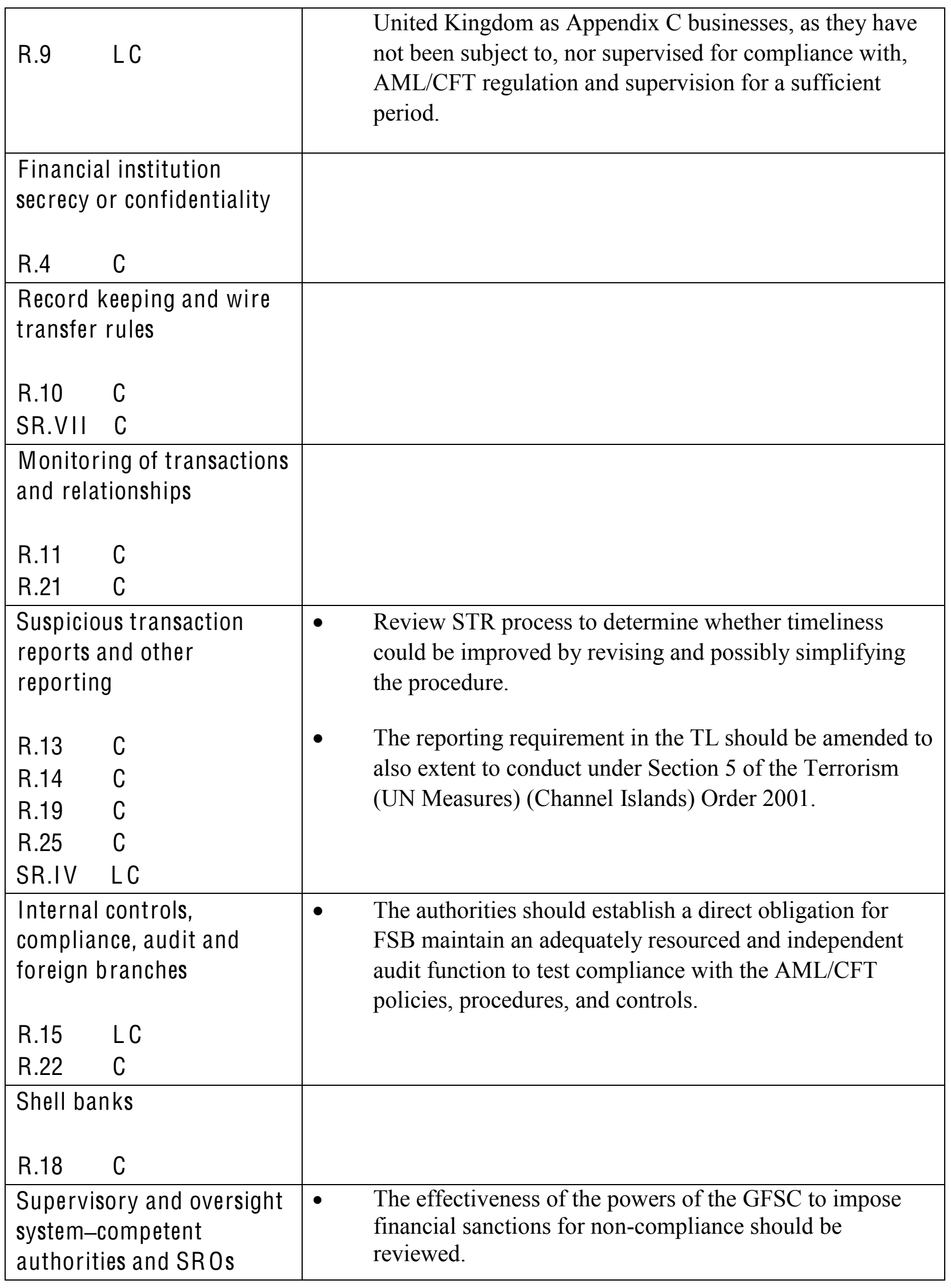




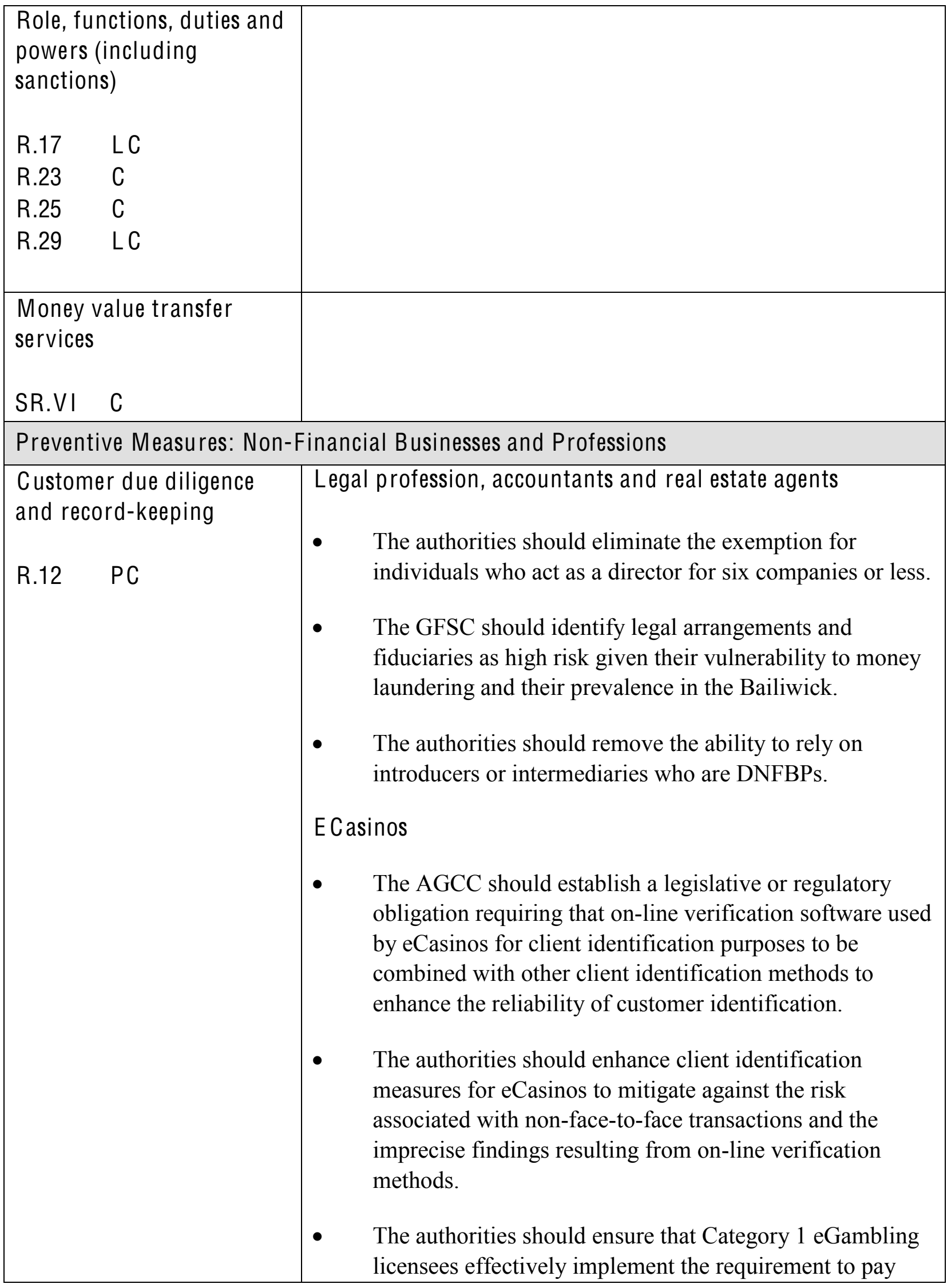




\begin{tabular}{|c|c|}
\hline & $\begin{array}{l}\text { special attention to complex and unusual transactions by } \\
\text { systematically reviewing gambling transactions facilitated } \\
\text { by Category } 2 \text { eGambling licensees. }\end{array}$ \\
\hline $\begin{array}{l}\text { Suspicious transaction } \\
\text { reporting } \\
\text { R.16 LC }\end{array}$ & $\begin{array}{l}\text { The authorities should ensure that eCasinos suspicious } \\
\text { transactions detection mechanisms are appropriate to the } \\
\text { AML risk level of the sector and effectively detect } \\
\text { suspicious transactions. } \\
\text { The authorities should ensure that AML/CFT training } \\
\text { requirements apply to all eCasino employees and } \\
\text { specifically require training on money laundering } \\
\text { techniques or employee obligations regarding CDD and } \\
\text { reporting. }\end{array}$ \\
\hline $\begin{array}{l}\text { Regulation, supervision, } \\
\text { monitoring, and sanctions } \\
\text { R.24 LC } \\
\text { R.25 LC }\end{array}$ & $\begin{array}{l}\text { - The authorities should ensure that police record checks are } \\
\text { conducted systematically on key individuals seeking an } \\
\text { eGambling license. } \\
\text { - The GFSC should, as it has recognized, increase the } \\
\text { frequency of its on-site inspections for TCSPs. } \\
\text { The AGCC should provide more guidance with respect to } \\
\text { AML requirements particularly in the area of customer } \\
\text { due diligence. }\end{array}$ \\
\hline $\begin{array}{l}\text { Other designated non- } \\
\text { financial businesses and } \\
\text { professions } \\
\text { R.20 C }\end{array}$ & \\
\hline \multicolumn{2}{|c|}{ Legal Persons and Arrangements \& Nonprofit Organizations } \\
\hline $\begin{array}{l}\text { Legal Persons-Access to } \\
\text { beneficial ownership and } \\
\text { control information } \\
\text { R.33 C }\end{array}$ & \\
\hline $\begin{array}{l}\text { Legal Arrangements- } \\
\text { Access to beneficial } \\
\text { ownership and control } \\
\text { information }\end{array}$ & $\begin{array}{l}\text { - The authorities should put in place specific measures to } \\
\text { ensure the availability of accurate and complete beneficial } \\
\text { ownership information for trusts and general partnerships } \\
\text { that are not administered by licensed TCSPs is available. }\end{array}$ \\
\hline
\end{tabular}




\begin{tabular}{|c|c|}
\hline$\overline{R .34}$ & \\
\hline Nonprofit organizations & $\begin{array}{l}\text { - The authorities should require manumitted organizations } \\
\text { to register as NPOs. } \\
\text { - The authorities should conduct outreach to the entire NPO } \\
\text { sector focused on the raising awareness of the risks of } \\
\text { terrorist abuse. } \\
\text { The authorities should require information on the purpose } \\
\text { and objectives of the NPO and the identity of the persons } \\
\text { who own, control or direct their activities to be made } \\
\text { publicly available. } \\
\text { The authorities should undertake supervision of all } \\
\text { categories of NPOs. } \\
\text { The authorities should strengthen the sanctions regime for } \\
\text { non-compliance with registration requirements to ensure } \\
\text { its effectiveness and dissuasiveness. }\end{array}$ \\
\hline \multicolumn{2}{|c|}{ National and International Cooperation } \\
\hline $\begin{array}{l}\text { National cooperation and } \\
\text { coordination }\end{array}$ & \\
\hline $\begin{array}{l}\text { The Conventions and UN } \\
\text { Special Resolutions }\end{array}$ & $\begin{array}{l}\text { - The Bailiwick should work to resolve issues with the } \\
\text { United Kingdom in order to be in a position to request an } \\
\text { extension of the ratification of the Palermo Convention to } \\
\text { it. } \\
\text { - The authorities should continue efforts to improve the } \\
\text { effective application of the ML provisions with the } \\
\text { development of cases involving financial sector } \\
\text { participants, and by addressing the disconnect between the } \\
\text { number of ML cases investigated versus the cases } \\
\text { prosecuted and eventually resulting in a conviction. }\end{array}$ \\
\hline $\begin{array}{ll}\text { R.36 } & \text { LC } \\
\text { R.37 } & \text { C } \\
\text { R.38 } & \text { LC }\end{array}$ & $\begin{array}{l}\text { While the recent legislative amendments de facto } \\
\text { eliminate the designation mechanism and thus any } \\
\text { concern on this point for future cases, prior to July } 2010 \\
\text { the designation mechanism may have had a negative } \\
\text { impact on the overall effectiveness of Guernsey's MLA }\end{array}$ \\
\hline
\end{tabular}




\begin{tabular}{|c|c|c|}
\hline SR.V & LC & framework. \\
\hline Extra & & \\
\hline R.39 & C & \\
\hline R.37 & C & \\
\hline SR.V & C & \\
\hline $\begin{array}{l}\text { Other } \\
\text { Coop }\end{array}$ & $\begin{array}{l}\text { orms of } \\
\text { tion }\end{array}$ & \\
\hline R.40 & C & \\
\hline SR.V & C & \\
\hline Othes & sues & \\
\hline Resol & es \& Statistics & \\
\hline R.30 & C & \\
\hline R.32 & C & \\
\hline
\end{tabular}




\section{H. Authorities' Response}

The Bailiwick authorities are fully committed to meeting the standards set by the FATF Forty Recommendations on Money Laundering and the Nine Special Recommendations. This commitment is reflected in the report, which identifies that the Bailiwick of Guernsey has a comprehensive AML/CFT legal framework and that this framework provides a sound basis for an effective AML/CFT regime. As evidenced by the effectiveness of the AML/CFT Advisory Committee, there is comprehensive co-ordination and co-operation between the AML/CFT authorities in the Bailiwick. The Bailiwick will continue to place a very high priority on co-operation, co-ordination and information exchange with authorities both locally and in other jurisdictions.

The Bailiwick has an on-going programme to review and enhance AML/CFT legislation, regulation, rules and guidance; monitor effectiveness of compliance with the AML/CFT regime; and address identified shortcomings. The recommendations made by the IMF have been, and will continue to be, taken seriously. Work on addressing the shortcomings began as soon as the IMF evaluation team left the Bailiwick.

Most of the recommendations made by the assessors are technical in nature, with some relating to the improvement of implementation of legislation. Even since the on-site element of the IMF's evaluation, steps taken by the Bailiwick's AML/CFT authorities over several years have produced enhanced results.

The first prosecution for autonomous money laundering has come to trial and the defendant has been convicted on nine different counts. There has also been a further successful money laundering prosecution involving two counts of self-laundering. This trend is expected to continue, with further successful money laundering prosecutions for both self laundering and autonomous money laundering anticipated.

As identified by the assessors, the confiscation and provisional measures within the Bailiwick are robust and are used routinely in all prosecutions where they can be applied. Since the on-site element of the IMF's evaluation a confiscation order in the sum of $£ 268,556$ has been made. This is the biggest domestic confiscation order made to date and arose from a non-drug trafficking case. In addition, following the successful prosecution for autonomous money laundering, an application will be made for a confiscation order in excess of $£ 300,000$.

Since the on-site visit, the effectiveness of the sanctions for breaching controls on cross border cash movements has also been demonstrated by the first prosecution under the cash controls legislation, which resulted in a $£ 2,000$ fine and confiscation of all the money involved (nearly $£ 10,000$ ) even though it was legitimately sourced.

The assessors had a concern that the then designation mechanism may have had a negative impact on the overall effectiveness of the mutual legal assistance system. The designation requirement was removed with effect from 28 July 2010. 
Recommendations were made by the assessors to enhance the requirements for the freezing and confiscation of terrorist assets. These will be addressed in the legislation which is being drafted to replace the current framework. In addition, further guidance has been provided to the financial sector in respect of the freezing and confiscation of terrorist assets and the Sanctions Committee will continue to monitor its effectiveness.

Several of the assessors' recommendations will be considered in the context of the proposed revisions to the FATF Recommendations. 